\title{
HILL LAKES: INNOVATIVE APPROACH FOR SUSTAINABLE RURAL MANAGEMENT IN THE SEMI-ARID AREAS IN TUNISIA
}

\author{
BOUFAROUA M. ${ }^{1, *}$ \\ SLIMANI M. ${ }^{2}$ \\ OWEIS T. 1 \\ ALBERGEL J. ${ }^{3}$
}

\author{
${ }^{1}$ International Center for Agricultural Research in the Dry Areas (ICARDA) \\ Integrated Water and Land Management Program \\ P.O. Box 950764, Amman 11195, Jordan \\ 2 Institut National Agronomique de Tunis (INAT) \\ Département de Génie Rural \\ 43 Avenue Charles Nicolle, 1082, Tunis Mahrajène, Tunisie \\ 3Institut de Recherche pour le Développement (IRD) \\ Département des affaires européennes \\ Le Sextant - 44, bd de Dunkerque, 13572 Marseille Cedex 02, France
}

Received: 06/07/12

Accepted: 04/10/12 *to whom all correspondence should be addressed: e-mail:m.boufaroua@cgiar.org

\begin{abstract}
In Tunisian semi-arid regions, where water is a rare commodity and the large dams cannot be justified considering the very limited water contributions and the very high evapotranspiration, innovative techniques of harvesting water have been adopted. Tunisia has initiated a policy of small dam construction aiming to combine land and water management with socioeconomic development. They also target erosion control and protection of downstream infrastructure.

Integrated rural development is achieved through the provision of a scarce but vital renewable resource.

Using the results of multi-disciplinary research carried out in a network of 25 hill lakes implemented in a semi-arid area, the present article shows the role of small dams in the mobilization and management of water and soil resources.

The issues involved in integrated development around hill reservoirs are closely linked to the sustainability of water. The agricultural development must be adapted to the life expectancy of the dam and the availability of water in dry periods. The recharge of the groundwater in the aquifers improves the potential for development. However, the impact of the stored water on health must be studied.

The environmental impact of the lake structures is linked to the quality of the water and the maintenance of its supply.
\end{abstract}

KEYWORDS: Hill lake, semi-arid zones, soil and water conservation, impact.

\section{INTRODUCTION}

Conscious of the gravity of the problem of lack of water resources, Tunisia is equipped with important hydraulic structures marked by the implementation of big dams. The most important is the dam of Sidi Salem on the Oued Medjerda in the governorate of Béja $\left(57 \mathrm{~m}\right.$ high and $700 \mathrm{Mm}^{3}$ of capacity). The objectives of such works are multiple: drinkable water supply, creation of irrigated perimeters, inundation control and production of electric power.

Innovative techniques of water and soil conservation were adopted in several zones of the country. This is particularly in the dry and semi-arid regions, where water is a rare commodity and large hydraulic structures cannot be justified considering the very limited amounts of water contributed and the very high evapotranspiration. Different water harvesting practices were developed from national to local strategies for better rural development aiming at sustainable human development and regional balance. So, Tunisia included the mobilization of water resources, rare and vital, in its 
strategic choices of development policy to satisfy the demand for drinking water and to develop irrigated perimeters as an objective of food self-sufficiency.

The climatic regions most vulnerable to soil loss are the semi-arid areas (Woodward, 1995; WCD, 2000 ) while the geographical area with the highest rate of siltation is Africa (on average about $19 \%$ of reservoir storage volume; ILEC, 1993, 2003; UNEP, 1994). During recent decades, research has emphasized the importance of soil erosion in the Mediterranean basin where siltation reduces reservoir capacity rapidly (e.g. Imeson, 1990; Poesen and Hooke, 1997; EEA, 2000; MartínezCasasnovas, 2003). In this region, the water needs amount to close to the potentially available water resources (e.g. Ennabli et al., 1998), and water is becoming increasingly expensive and a heavy burden for the economy.

Tunisia was one of the countries within the Mediterranean basin classified among the first ten, worldwide, that would suffer from water scarcity (FAO, 1994).

The problem of water resources and to balance the capacity loss of reservoirs in the rural zones inspired Tunisian engineers to propose innovative solutions to harvest the rare available surface water resources by the construction of hill lakes (small dams). The originality of such an approach was in reviewing the classic reasoning, which always considered that the task of collection of surface water required large dams with considerable dikes and very high costs. A policy of construction of hill lakes was adopted at moderate cost, allowing not only the mobilization of water resources and protection against erosion but also protection from inundation and strong floods (Boufaroua, 2007). In fact, more than 1000 hill lakes were built in in semi-arid areas in Tunisia.

In Tunisia, the hill lakes have become the keystone of the national soil and water conservation strategy (Sources: Ministry of Agriculture, Directorate of Water and Soil and Conservation). By introducing policies recognising the value of ecosystem services and the role of rainfall to support these systems, rain water harvesting emerges as a set of interventions addressing multiple issues on human well-being and improved ecosystems services (Barron, 2009). The strategy of hill lakes implementation contributes in a sustainable water management and its objectives are (Talineau et al., 1994):

- To reduce losses of agricultural land (estimated at 10,000 ha per year);

- To reduce dam siltation (25 $\mathrm{Mm}^{3}$ per year in 1990);

- To increase water table recharge;

- To mobilize as much as possible of the $500 \mathrm{Mm}^{3}$ of water lost to the sea or to the Sebkhas (salty lakes);

- To create points for the development of irrigated cropping.

Using results of research monitoring program in a network of 25 hill lakes, in the semi-arid zone of Tunisia, this article shows the role of small dams in the development and conservation of agricultural land to contribute to the sustainable development in these poor areas.

\section{MATERIAL AND METHODS}

\subsection{Study area and observed network}

The Dorsal Mountains represent the last part of the Atlasic Mountain Range toward the east. The major peaks correspond roughly to $1000 \mathrm{~m}$. The Dorsal Mountains correspond approximately to the $400 \mathrm{~mm} /$ year rainfall isohyet (see Figure 1.a). Although the annual amount is small, rainfall is often characterized by intense storms during some periods of the year. Annual rainfall is in the range of 250-550 mm. Both annual and monthly rainfalls are characterized by large irregularities. Twenty-five hill lakes were chosen to constitute the observed network. Due to specific bioclimatic conditions of the Mediterranean climate, the soils are better characterized by the degradation of rock material rather than their organic matter content. Consequently, soil erosion is a serious problem (Jebari et al., 2008). The Dorsal Mountains area was monitored by a hydrological observation network with 25 experimental catchments (see Figure 1.b). 


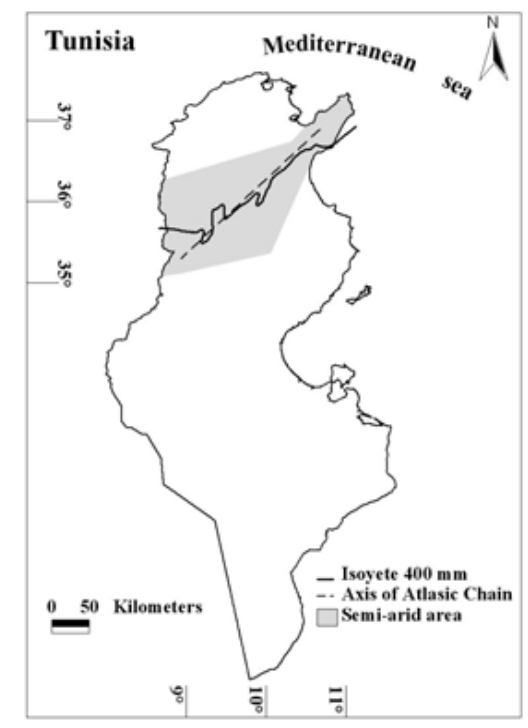

Figure 1.a. Study area

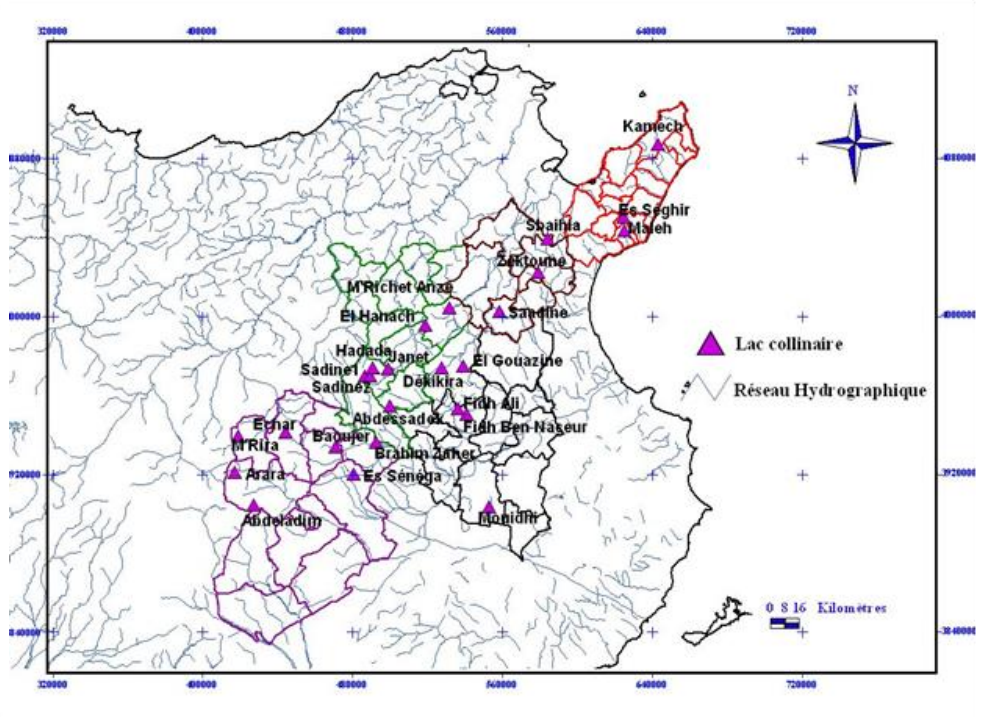

Figure 1.b. Observed network (25 hill lakes)

Each catchment discharges into a small reservoir. An automatic rain-gauge is located at each site as well as automatic water level recording. The average area of 25 of these catchments is about $4 \mathrm{~km}^{2}$. The average drainage density of the catchments is $5.1 \mathrm{~km} / \mathrm{km}^{2}$. Their mean height difference is about $245 \mathrm{~m}$, and the mean average slope is $11.2 \%$. The value concentration time is about $11 \mathrm{~min}$. The average runoff coefficient is about $10 \%$, but values of up to about $80 \%$ have been recorded for some intense rainstorms (Jebari et al., 2008).

\subsection{Methods}

In order to reach the objectives of an adequate land management, an integrated approach, based on a methodological study and a planning, which permit to find practical and rational solutions around the created reservoirs.

The approach is to protect the downstream of watersheds from sedimentation, and floods, and to improve revenues of farmers and livestock herders established in the upper parts of the watersheds. The integrated conservation management was considered at three levels: technically, socioeconomically and environmentally.

The 25 units of hill lakes of our network were carefully observed and the data characterizing the observed hill lakes collected..

The above experimental catchments were investigated through field trips and interviews with local farmers, inhabitants and national and local scientists. The useful information is analysed to provide solutions to user needs: user experts, public and private and research communities. The archived data could be used as specific information for interest to specific group or projects (rural management, control of drought, pollution ...) or to improve the existing multisource data in the country.

In this article the available information is treated to show the role of hill lakes in: i) harvesting water resources, ii) controlling erosion and protecting infrastructure, iii) improving environment and human well-being, for assessing the contribution of hill lakes to sustainable rural management.

\section{ROLE AND IMPACT OF THE HILL LAKES}

The actions of conservation of water and soils aim essentially at preservation and improvement of the fertility of the land, control of erosion, mobilization of a part of surface runoff, the protection of infrastructure, improvement of agricultural production, creation of employment and the profitable improvement of the income of the beneficiaries (Boufaroua et al., 2009). As for hill lakes more particularly, we detail their effects and their impacts in the following paragraphs. 


\subsection{Water conservation and better local development}

The runoff that fills the hill lakes is generated by heavy rainfall. It often needs only two or three rainfall events and sometimes only one to fill a reservoir. In the semi-arid Tunisian climate, these most often occur in autumn and winter, but a strong summer storm can generate enough runoff to cause a discharge. The high rates of evaporation from the lakes, together with their shallowness, do not allow the water to be kept for long. In Figure 2, we give an example of reconstruction of the runoff contributions and the rain intensities in Kamech Lake in the governorate of Nabeul. Most of the collected water in this hill lake came from the storm registered for 27-30 November 1999 (Boufaroua et al., 2000).

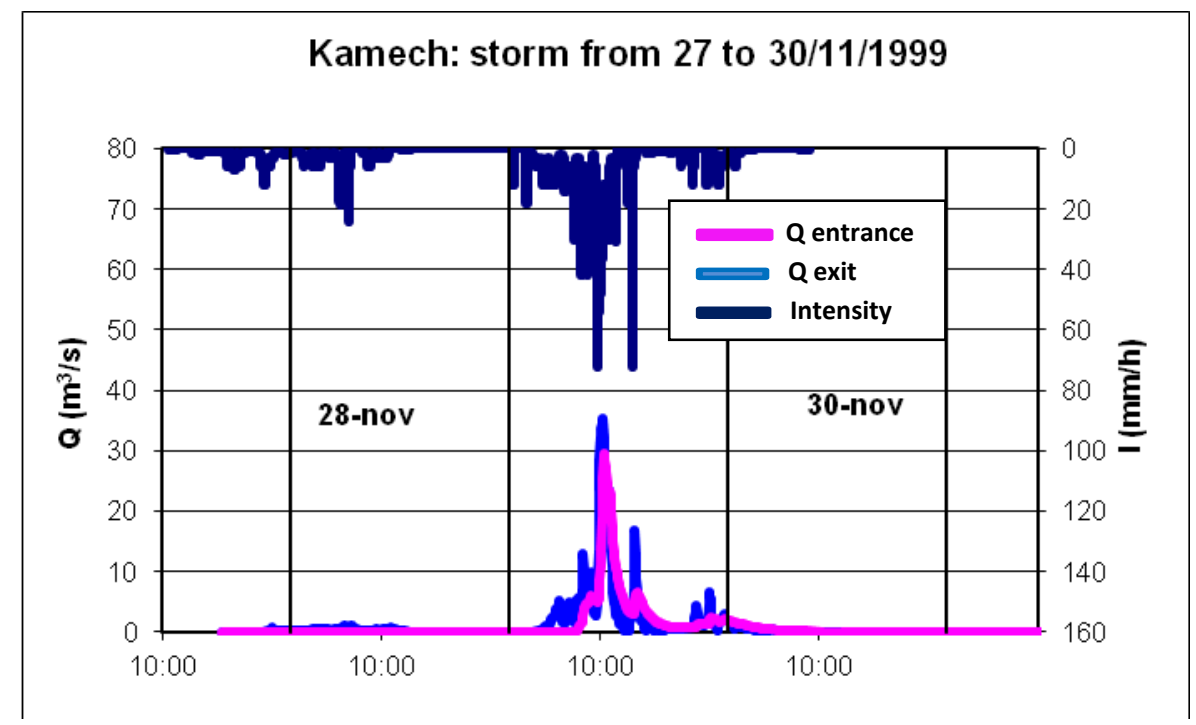

Figure 2. Reconstruction of Runoff events at Kamech Hill Lake

Figure 3 shows, for Es-Senega Hill Lake in the governorate of Kasserine: (i) the daily precipitation, (ii) the levels of water in the dam and (iii) the level of siltation at the foot of the dam. The spillway level and that of the top of the dike are indicated (Figure 3), making it possible to highlight the discharges (Boufaroua et al., 2009).

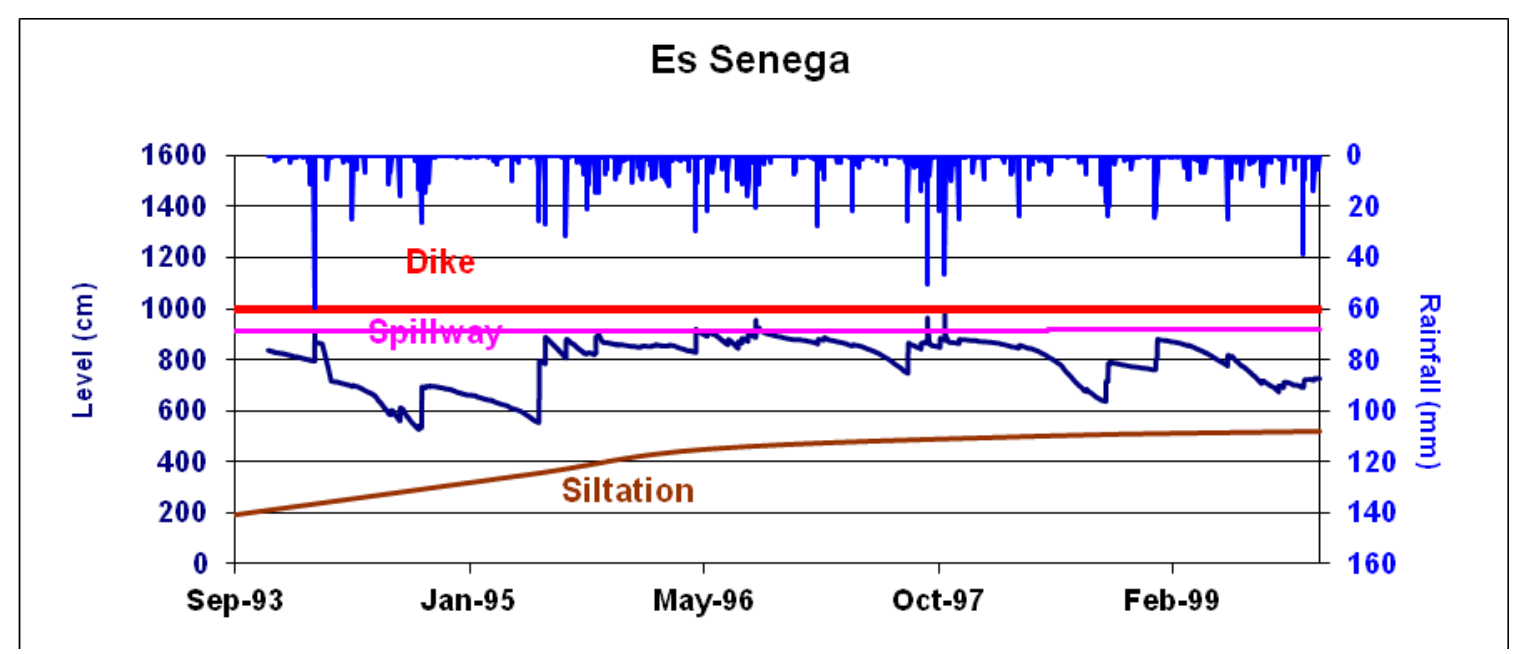

Figure 3. Rainfall data, levels and siltation observed on the hill lake of Es-Senega in central Tunisia for 1993 to 1999

The temporarily stored water can be used in a number of ways. The Tunisian hill lakes are generally situated in landscapes of small mountains with poor natural resources and important socio- 
institutional handicaps. The storage of water runoff and its provision for varied uses constitutes an important pillar for the development of the semi-arid zones (Boufaroua et al., 2009).

An analysis of the agricultural production systems around the 25 hill reservoirs in Tunisia demonstrated the dynamics of agricultural development. It showed that:

- $75 \%$ of farmers had introduced irrigation and adopted the integrated management into their system of agricultural production,

- $25 \%$ of farmers had not introduced irrigation and were maintaining their traditional system of production (Boufaroua et al., 2009).

For comparison, a study conducted in the same location during $1993-1996$ showed that only $25 \%$ of farmers used the irrigation systems in their farms (Selmi, 1996).

The hill lakes as small-sized hydraulic structures with an average of capacity $118,000 \mathrm{~m}^{3}$, supplement the large dams as far as surface water mobilization is concerned. The share of the mobilized resource is modest - the implemented units in Tunisia allowed the mobilization of 83.6 $\mathrm{Mm}^{3}$ of the surface water. They are mainly located in the semi-arid region $(68 \%$ in the Dorsal Mountains) (Boufaroua et al., 2009). However, this represents $17 \%$ of the surface water that the large dams were considered unable to mobilize $\left(500 \mathrm{Mm}^{3}\right.$ per year). The resource is distributed within rural areas, often reaching regions that have neither a large dam nor any important underground water resource. The use to which this water is put depends largely on the life expectancy of the structure. The possibility of recharging the phreatic water tables from these reservoirs allows a significant amount of water to be saved for use during summer.

This water is essential for all living beings, for consumptive use. Plants and vegetation are by far the largest water consumers, but they also provide direct livelihood and economic returns to humans as food, fodder, fibre and timber, in addition to fresh water, products for pharmaceutical use and diverse genetic resources (Barron et al., 2009).

\subsection{Erosion control and infrastructure protection function}

Siltation measurements were made on the basis of bathymetric observations in reservoirs in the network of 25 hill lakes mentioned above. Measurement campaigns started in 1993, with up to five observations for each reservoir. Depending on the reservoir, there were 400-700 measuring points used. The points were defined by three Cartesian coordinates $(x, y, z)$. The change in reservoir volume was deduced from the difference between one observation time and another.

A digital model of the terrain was constructed. Comparison of the reservoir volumes at discharge level between one measurement and another was used to estimate the amount of material retained. A mean concentration of suspended matter, obtained by sampling, was attributed to the discharged volumes. Solid transport between two bathymetry measurements was obtained by adding the mass of soil exported by the discharged liquid flows to the volume of silt retained in the dam, and multiplied by its density.

$T_{\text {sobs }}=\left(V_{\text {vobs }} x d\right)+\sum V_{d e v} x c$

where $\left(T_{\text {sobs }}\right)$ is the total solid transport between two bathymetry measurements, $\left(\mathrm{V}_{\text {vobs }}\right)$ the measured volume of silt, $d$ the density of the silt, $\left(V_{\text {dev }}\right)$ the volume discharged during the flood and (c) the measured concentration of suspended matter during the flood. This method provides a good estimation of the solid transport at the outlet of a reservoir catchment. It incorporates the soil losses due to all three forms of water erosion: (i) sheet erosion caused by rainwater runoff on the plots on the slopes, (ii) gully erosion caused by concentrated runoffs on portions of the slopes and (iii) bank erosion produced by variations in the runoff regime.

A model was used to simulate the inputs flood-by-flood that had been validated and applied to the 25 hill lakes in our study area (Boufaroua et al., 2000).

Siltation in the different catchments ranged from $0.9 \mathrm{~m}^{3} / \mathrm{ha} / \mathrm{year}$, for a fairly wooded piedmont catchment where a lot of erosion control work has been done (El Gouazine), to $22 \mathrm{~m}^{3} / \mathrm{ha} /$ year for a small, very marly catchment (Saadine).

The 25 hill lakes had a total initial storage capacity of about 2.7 Mm3 for the period 1996/1997$2003 / 2004$. They lost $839,000 \mathrm{~m}^{3}$, which represents $30 \%$ of their total capacity of storage for the duration of an average existence of 10 years, or an annual loss average of $3 \%$ of the total capacity of storage. 
In conclusion, the life expectancy average of the 25 hill lakes was as follows: $20 \%$ of the lakes have a life expectancy of 20 years and approximately $32 \%$ have a life expectancy of 50 years. The average life expectancy of all the lakes was about 47 years without taking into account extreme values.

In conclusion, a small artificial reservoir at a catchment outlet is an ideal location for observing the solid matter transported by the water system. It is easy to estimate this solid transport by making regular bathymetry measurements, taking samples of the discharges and monitoring the water balance of the reservoir.

\subsection{Environmental impacts}

The implementation of hill lakes creates a long-lasting water resource over several months in the rivers of semi-arid areas, where the floods pass in only a few hours and strongly modify the environment. The landscape acquires a new aspect: the hill lake occupies a variable surface following the capacity of the reservoir and according to the season. Certain lakes have a multiannual filling, and others dry up during a relatively long period. During such dry periods dead aquatic vegetation can be seen sprinkled over dry and cracked clayey lake beds.

The measured salinities were generally satisfactory for a variety of uses. Three geochemical groups were identified in the period of surface inputs into the reservoirs. The reservoirs in the Zeroud and the Merguellil catchments (central Tunisia), where there is a considerable presence of gypseous formations, are characterized by calcic sulfated water. This water is the most heavily loaded with salts, and the increase in salinity by evaporation can limit its use for irrigation. Calcic bicarbonated water, found above all in the sub-catchments of the Medjerdah (center and north of the country), where the dominant geological formations are alternations of limestone and marl, is far more diluted and presents fewer constraints. Two reservoirs located in Cap Bon are distinct in having water of low salinity but sodic chlorinated (Rahaingomanana, 1998).

The presence of a quantity of water over a relatively long period allows new florae and faunae to establish an ecosystem. We can notice the spectacular development of batrachians, snakes, birds of water and the appearance of species of fishes (naturally or by voluntary introduction); however, no quantitative study was made. Regarding the vegetation, water plants appear on the lake borders, but it is necessary to note the disappearance of plants not tolerant to flooding for the benefit of hydrophilic plants. Numerous forest plantations have been grown, following the construction of the hill lakes.

An analysis of the risks of pollution by agricultural effluents was conducted in the catchment of the small dam at Kamech (Vateau, 2003). No pesticides used by farmers were found in significant quantities in the water analyzed in early summer. Pollution by nitrogen fertilizers was within acceptable limits. These results can be extrapolated to all reservoirs in a rural environment other than those where intensive farms have been established near the small dams (Albergel et al., 2004).

\subsection{Impacts on the recharge of the superficial aquifers}

The study of the contribution of the small hydraulic structures in recharging aquifers is a difficult task because of the need for a long period of observations. However, the study conducted in the chosen network in the semi-arid zone of Tunisia allowed the establishing of a hydrological balance assessment on a daily scale, which enables evaluation of underground exchanges of water (a positive volume indicates a contribution of the aquifer towards lake, and a negative volume an infiltration).

The calculation of the infiltrated volumes showed an effective refill of the alluvial aquifers for 14 of the 25 lakes. Surface wells downstream of the reservoir had water levels rise by $>20 \mathrm{~m}$. This was the case of the hill lake of El Gouazine, at the foot of Jebel Serj in Tunisia, where the water level in two wells downstream of the reservoir had risen about $10 \mathrm{~m}$ since the lake's construction in 1990. The calculated volume that infiltrated for the year $1995-1996$ was $275,000 \mathrm{~m}^{3}(125 \%$ of the volume of the reservoir) and for a lower year 1998-1999 a volume of 135,000 $\mathrm{m}^{3}$. The aquifer rose by $2 \mathrm{~m}$ for the autumnal period of 1995 (Nasri, 2002). Such rises of water are sometimes accompanied by a deterioration of the chemical quality of water. In the case of El Gouazine, the concentration in dissolved substances was $2 \mathrm{~g} / \mathrm{l}$ in the lake and $3.5 \mathrm{~g} \mathrm{l}^{-1}$ in wells (Nasri, 2002). 


\subsection{Impacts on the human health}

In Tunisia, the presence of hill lakes in rural regions contributes to the development of the agriculture by allowing the development of irrigated zones, water for the livestock and the installation of fish farming. These lakes also contribute to the promotion of tourism.

Nevertheless, stagnant water in the reservoirs may be the origin of some diseases. To date, public health surveys do not indicate any new outbreaks or the appearance of new illnesses associated with these hill lakes. Diseases transmitted by mosquitos are monitored very closely. The collected water of these hill lakes is generally convenient to introducing varied aquatic fauna that participate in the cycles of certain germs and pathogenic parasites affecting human health; the major risk is the reintroduction of the malaria by the vectors Anopheles spp., which are particularly favored by such collections of fresh water. Leishmanioses and certain emergent vectorial viral infections are also of a high risk. A strict and permanent surveillance of the collected water, as well appropriate measures of prevention are imperative to reduce any sanitary risk and to optimize the profit obtained by use of these hill lakes (Boufaroua et al., 2003).

\section{CONCLUSIONS}

The 'hill lake' is one of the most important components of the national strategy of preservation of water and soils in Tunisia. The harvested water aims at ensuring a supplemental amount of water that can contribute to local and regional development in the dry areas.

The results of the research program in 25 hill lakes in the semi-arid region in Tunisia shows that hill lakes have an important role in the development of agricultural land and as focal points for local agricultural development.

Storage reservoirs are good sediment traps. They protect downstream infrastructure and can prolong the life of larger dams located downstream. Recharging the alluvial water table is in many cases a realistic objective, but an appropriate dam site must be chosen. They have an interesting life expectancy with an average of 47 years.

From an environmental point of view, the impacts are positive, provided that water quality is maintained by paying attention to possible effluent. Hill lakes are usually located in rural environments with a low population density, and so are adequately protected. They are small wetland areas, contributing to biological diversity and the protection of birds and other animals.

Implanted in fragile environments with low economic activity, hill lakes are perceived as an additional, vital but uncertain resource. The choice of the sites and the management of the lakes must be in touch with precise objectives such as protection, exploitation and recharge of aquifers. They may stabilize rural populations by assuring them of real possibilities of development in poor, isolated and disadvantaged locations. Their presence and their promotion are a strategic interesting choice allowing the mobilization of natural hydraulic resources to meet water requirements for agriculture, industry and tourism (Boufaroua and al., on 2000).

The objectives must be increasingly prioritized into a hierarchy and studied from technical and socioeconomic aspects within the framework of a participative approach that integrates the beneficiaries as decisive partners.

\section{REFERENCES}

1. Albergel J., Pepin. Y., Nasri S. and Boufaroua M. (2003) Erosion et transport solide dans des petits bassins versants méditerranéens. In Hydrology of the Mediterranean and Semi-arid Regions. Proceedings of an international symposium held at Montpellier, April 2003 IASH Publ. $n^{\circ} 278,373-$ 379.s

2. Albergel J., Nasri. S., Boufaroua M., Droubi. A. and Merzouk A. (2004) Rain Water Harvesting and Management of Small Dams in Mediterranean Areas (North Africa and Middle East). Proceedings of an international symposium held at Republic of Macedonia, May 2004.

3. Barron J. (2009) Rainwater harvesting: a lifeline for human well-being. A report prepared for UNEP by Stockholm Environment Institute.

4. Boufaroua M., Albergel J. and Pépin Y. (2000) Bilan de l'érosion sur les petits bassins versants des lacs collinaires de la dorsale tunisienne. Annuaire des publications de l'association internationale des géologues, 1209-1216.

5. Boufaroua M., Tiouiri H. and Aoun K. (2003) Hill lakes and human health: the example of Tunisia. Livre des publications IASH, Tunisie.

6. Boufaroua M. (2007) Les lacs collinaires Tunisiens: l'innovation de l'ingénieur tunisien, Revue de l'Ingénieur Tunisien, 36, 16-26. 
7. Boufaroua M., El Mourid M. and Ben Khlifa W. (2009) Techniques de conservation des eaux des sols dans les zones arides et semi-arides de la Tunisie. Annuaire des publications de l'association du Téthys, Université du Caire, 99-108.

8. EEA (European Environmental Agency) (2000) Down to earth: Soil degradation and sustainable development in Europe. Environmental issue series no. 16, European Environmental Agency.

9. Ennabli M., Margat M. and Vallee D. (1998) Pour prévenir les crises de l'eau en Méditerranée, priorité à une meilleure maîtrise des demandes. Proc. Conf. Int. "Eau et Développement durable" (Paris, 19-21 Mars).

10. FAO (1994) Situation mondiale de l'alimentation et de l'agriculture 1993. FAO Agriculture no. 26, Food and Agriculture Organization of the United Nations, Rome, Italy.

11. ILEC \& Lake Biwa Research Institute (eds) (1988-1993) Survey of the State of World Lakes, vols IV. ILEC/UNEP, Kusatsu/Nairobi, Kenya.

12. Imeson A.C. (1990) Climate fluctuations and soil erosion under Mediterranean conditions. Technical Report, Menéndez Pelayo Int. Univ., Valencia, Spain

13. Jebari S., Berndetsson R., Bahri A. and Boufaroua M. (2008) Exceptional Rainfall Characteristics Related to Erosion Risk in Semiarid Tunisia, The Open Hydrology Journal, 2008, 25-33.

14. Martínez-Casasnovas J.A. (2003) A spatial information technology approach for the mapping and quantification of gully erosion, Catena, 50, 293-308.

15. Nasri S. (2002) Hydrological effects of water harvesting techniques. A study of Tabias, soil contour ridges and hill reservoirs in Tunisia. PhD, Lund Institute of Technology, Lund University, Lund.

16. Poesen J.W.A and Hooke J.M. (1997) Erosion, flooding and channel management in the Mediterranean environments of southern Europe, Prog. Phys. Geogr., 21, 157-199.

17. Rahaingomanana N. (1998) Caractérisation géochimique des lacs collinaires de la Tunisie semiaride et régulation géochimique du phosphore, Thèse de doctorat en Hydrologie, Université Montpellier I.

18. Selmi S. (1996) Interventions de l'état en milieu rural et réactions des collectivités locales face à la gestion d'une ressource rare les lacs collinaires dans le semi-aride Tunisien. Thèse de doctorat en économie du Développement Agricole, Agro-alimentaire et Rural, Ecole nationale Supérieure Agronomique de Montpellier.

19. Vateau C. (2003) Diagnostic de pollution agricole sur le bassin versant de Kamech (Cap Bon, Tunisie). DAA Agro Environnement de l'ENSAM, Montpellier.

20. Talineau J.C; Selmi, S.; Alaya, K. (1994) Lacs collinaires en Tunisie semi-aride, Sécheresse (FRA), 5(4), pp. 251-256.

21. WCD (World Commission on Dams) (2000) Dams and Development. A New Framework for Decision-Making. Earthscan, UK.

22. UNEP (1994) The pollution of lakes and reservoirs (UNEP Environment Library). UNEP/Nairobi, Kenya.

23. Woodward, J. C. (1995) Patterns of erosion and suspended sediment yield in Mediterranean river basins, In: Sediment and Water Quality in River Catchments (ed. by I. D. L. Foster, A. M. Gurnell \& B. W. Webb), 365-389. John Wiley \& Sons, Chichester, UK. 